\title{
ANALISIS KOMUNIKASI ANTAR BUDAYA DALAM RITUAL KEDURAI AGUNG DI DESA TABA TEMBILANG KECAMATAN ARGAMAKMUR BENGKULU UTARA
}

\author{
Oleh : \\ YUPITA ADRIA, SAPTA SARI, YANTO \\ Program Studi Ilmu Komunikasi Fakultas Ilmu-Ilmu Sosial \\ Universitas Dehasen Bengkulu
}

\begin{abstract}
This study aims to determine the intercultural communication in Kedurai Agung ritual atTaba Tembilang Village Argamakmur District North Bengkulu. The data collection method used is observation, interview, and documentation. The theory used in this study is the theory according to Deddy Mulyana about intercultural communication that has a personal function and social function. Social function consists of social identity, declaring social integration, and adding knowledge. Social function consists of supervisory function, bridging function, socialization and entertaining.The results showed that intercultural communication express social identity can be viewed from the origin of tribes, religions, and different cultures. Social integration accepts the differences between each of the existing tribes, and appreciates each other in spite of different tribes. Adding knowledge to each other learns the values of culture in Kedurai Agung ritual.The social function of supervision supervises each other. Different cultures are a bridge over the differences to unite hospitalitywith people of different tribes and cultures. To socialize the cultural values in this village is very good because they realize the important of study the existing cultures. Intercultural entertainment is clearly visible from the information obtained because Kedurai Agung ritual held in Taba Tembilang village is held only once a year and although many different tribes have a sense of caring and mutual respect for others.
\end{abstract}

Keywords: intercultural communication, kedurai agung ritual, kedurai agung custom

\section{PENDAHULUAN}

Komunikasi merupakan salah satu aktivitas yang sangat fundamental dalam kehidupan umat manusia dan merupakan kebutuhan manusia untuk berhubungan dengan sesama. Dalam kehidupan, dan bahkan komunikasi menjadi suatu fenomena bagi terbentuknya suatu masyarakat atau komunitas yang terinteraksi oleh informasi, dimana masing-masing individu dalam masyarakat itu sendiri saling berbagi informasi untuk mencapai tujuan bersama.
Komunikasi merupakan suatu hal yang mendasar dalam kehidupan manusia. Dengan adanya berbagai macam model komunikasi dan proses komunikasi akan dapat ditemukan komunikasi yang cocok dan mudah digunakan dalam berkomunikasi sehari-hari. Proses komunikasi merupakan rangkaian dari aktivitas menyampaikan pesan sehingga menghasilkan feedback dari penerima pesan. Dari proses komunikasi, akan timbul model, simbol-simbol dan juga 
bagian-bagian kecil yang berkaitan erat dengan proses komunikasi.

Pada dasarnya, komunikasi menggambarkan proses penyampaian pesan yang mampu memberikan gambaran tentang sebuah sejarah dan fenomena yang terjadi akan bersifat spontan, komunikasi yang dilakukan oleh seseorang mampu menimbulkan dan mengahasilkan respon dan pendapat yang baik dari khalayak. Komunikasi yang efektif juga bisa dilakukan secara komunikasi dua arah yang menggunakan saluran yang baik pula.

Menurut Funk dan Wagnalls seperti yang dikutip oleh Muhaimin tentang istilah tradisi di maknai sebagai pengetahuan, doktrin, kebiasaan, praktek dan lain-lain yang dipahami sebagai pengetahuan yang telah diwariskan secara turun-temurun. Tradisi merupakan sebuah persoalan dan yang lebih penting lagi adalah bagaimana tradisi tersebut terbentuk.Tradisi atau kebiasaan (Latin: traditio,"diteruskan") adalah sesuatu yang telah dilakukan sejak lama dan menjadi bagian dari kehidupan suatu kelompok masyarakat, biasanya dari suatu negara, kebudayaan, waktu, atau agama yang sama. Hal yang paling mendasar dari tradisi adalah adanya informasi yang diteruskan dari generasi ke generasi baik tertulis maupun (sering kali) lisan, karena tanpa adanya ini, suatu tradisi dapatpunah. Manusia juga melakukan komunikasi sebagai cara untuk mengembangkan dan mempertahankan adat mereka.

Budaya yang berbeda memiliki sistemsistem nilai yang berbeda karena dapat menjadi salah satu penentu tujuan hidup yang berbeda pula. Cara setiap orang berkomunikasi sangat bergantung pada bahasa, aturan dan norma budaya masingmasing. Budaya juga mampu mempengaruhi kemampuan berkomunikasi seseorang dalam menyampaikan pesan kepada mereka, dan proses penyampaian pesan kepada masyarakat tentang pentingnya ritual kedurai agung juga sangat mempengaruhi masyarakat lain dan proses penyampaian pesan tersebut.

Makna hanya dapat disimpan di dalam simbol, Simbol adalah objek atau peristiwa apa pun yang menunjukkan pada sesuatu. Simbol itu meliputi apa pun yang dapat kita rasakan atau kita alami. Manusia berfikir, berperasaan, dan bersikap dengan ungkapanungkapan yang simbolis. Setiap orang, dalam arti tertentu membutuhkan sarana atau media untuk berkomunikasi. Media ini terutama ada dalam bentuk-bentuk simbolis sebagai pembawa maupun pelaksana makna atau pesan yang akan dikomunikasikan. Makna atau pesan sesuai dengan maksud pihak komunikator dan (diharapkan) ditangkap dengan baik oleh pihak lain. Makna-makna yang tertuang dalam simbolsimbol yang diwariskan melalui sejarah. Kebudayaan adalah sebuah sistem dari konsep-konsep yang diwariskan dan diungkapkan dalam bentuk simbol melalui mana manusia berkomunikasi, mengekalkan dan mengembangkan pengetahuan tentang kehidupan ini (Sobur, 2013: 177).

Budaya menjadi bagian dari perilaku komunikasi, dan pada gilirannya komunikasi pun turut menentukan, memelihara, mengembangkan atau mewariskan budaya. Sebagai pengetahuan, kebudayaan terdiri atas serangkaian nilai-nilai, norma-norma yang berisikan suatu tindakan dalam menghadapi suatu lingkungan sosial, kebudayaan, dan alam, serta berisi serangkaian konsep-konsep dan modelmodel pengetahuan mengenai berbagai tindakan dan tingkah laku yang seharusnya diwujudkan oleh masyarakat. Jadi nilai-nilai tersebut dalam penggunaannya adalah selektif sesuai dengan lingkungan yang dihadapi oleh masyarakat.

Komunikasi masyarakat memiliki keahlian menyampaikan pesan kepada masyarakat lainnya dan mereka akan 
menyampaikan pesan mereka kepada khalayak tentang sebuah kisah dan sejarah yang pernah terjadi di lingkungan masyarakat Rejang di kawasan Bengkulu Utara pada umumnya di Desa Taba Tembilang Kecamatan Argamakmur. Komunikasi sangat berperan penting dalam perkembangan budaya rejang di Bengkulu Utara, khususnya tentang adat Kedurai Agung di Desa Taba Tembilang Kecamatan Argamakmur. Masyarakat desa Taba Tembilang dalam memperkenalkan dan memberikan informasi dan pesan kepada masyarakat tentang arti dan manfaat ritual Kedurai Agung di Desa Taba Tembilang. Komunikasi dan budaya memiliki keterkaitan satu sama lainnya. Budayabudaya yang berbeda memiliki sistemsistem nilai yang berbeda contohnya desa Taba Tembilang yang memiliki masyarakat yang berbeda budaya, namun masyarakat yang berbeda budaya mengikuti aturan dan perayaan ritual Kedurai Agung yang selalu di adakan di desa tersebut.

Dahulu, upacara ritual ini dilakukan setiap setelah panen raya sebagai wujud tanda bersyukur, namun karena sekarang musim sering tidak menentu maka biasanya sekarang upacara ini dilakukan oleh masyarakat di desa Taba Tembilang setiap tahun tepatnya setiap hari raya idul fitri ke7. Karena pada saat lebaran sanak keluarga yang jauh masih berkumpul dengan keluarga besarnya. Kedurai adalah upacara melalui proses ritual dan agung diartikan besar jadi Kedurai Agung merupakan upacara ritual yang besar. Dalam pelaksanaannya upacara Ritual Kedurai Agung mengacu pada pemujaan terhadap arwah nenek moyang dengan menyuguhkan makanan sebagai sesajen khas. Upacara ini dilakukan sebagai upaya para leluhur untuk meminta keselamatan oleh yang maha kuasa dan menolak balak. Desa yang dihuni oleh masyarakat rejang asli Bengkulu Utara ini, juga merupakan keturunan Rejang Bermani,
Rejang Pat Petulai, Jang Tiang Pat, dan lainlain. Mengingat adat dan tradisi Kedurai Agung yang sering dilakukan oleh keturunan Bermani ini, hanya dirayakan dan dilaksanakan di desa Taba Tembilang. Jika perayaan ritual kedurai agung ini tidak dilakasanakan maka akan datang balak yang mengancam masyarakat desa Taba Tembilang seperti datangnya penyakit dan masuknya harimau mengganggu masyarakat masuk kedesa yang memberikan peringatan untuk melakukan ritual Kedurai Agung ini. Dari dulu sampai sekarang pelaksaan ritual Kedurai Agung ini selalu diadakan dan menjadi tradisi turun temurun yang dilestarikan di desa taba tembilang Namun keturunan Bermani, Jang Pat Petulai, Jang Tiang Pat di desa Taba Tembilang juga terdapat di desa Senali, Kurotidur, dan desa Tes Kecamatan Lebong.

Berdasarkan hasil observasi awal maka yang melatarbelakangi penulis mengangkat judul tentang analisis komunikasi antarbudaya dalam ritual Kedurai Agung yang ada di desa Taba Tembilang ialah, penulis ingin menganalisis komunikasi antarbudaya dalam ritual Kedurai Agung melalui masyarakat yang berbeda budaya yang menetap tinggal di desa Taba Tembilang ini. Karena tidak semua orang tahu dan paham tentang ritual kedurai agung ini terkhusus masyarakat yang bukan suku rejang seiring perkembangan zaman yang semakin modern dan canggih seperti sekarang dikalangan masyarakat rejang tradisi ini sudah mulai memudar, karena ketidak tahuan dan paham apa itu tradisi Kedurai Agung yang ada di desa mereka. Tradisi Kedurai Agung yang terjadi di desa Taba Tembilang bahwa menjelang Kedurai Agung. Selain kerjasama juga terciptanya hubungan yang baik antar sesama warga, karena dalam kegiatan ini mereka dapat saling bersilaturahmi dan bergotong-royong sesama warga. Setelah penulis melihat tradisi yang terjadi di desa Taba Tembilang 
penulis tertarik untuk melihat komunikasi antarbudaya dalam ritual Kedurai Agung karena tradisi Kedurai Agung yang ada di desa Taba Tembilang ini dilaksanakan setiap satu tahun sekali dan merupakan kebudayaan secara turun-temurun keturunan Rejang yang ada di Desa Taba Tembilang dan seperti apa rangkaian proses pada saat menjelang ritual adat Kedurai Agung tersebut.

Adapun tujuan dari penulisan ini untuk mengetahuianalisis komunikasi antarbudaya dalam ritual Kedurai Agung di desa Taba Tembilang Kecamatan Argamakmur Bengkulu Utara.

\section{METODE PENELITIAN}

Artikel ilmiah ini menggunakan metode penelitian kualitatif, yaitu penelitian yang diteliti secara langsung kepada narasumber atau objek penelitian sehingga menghasilkan data deskriptif. "Penelitian kualitatif adalah prosedur penelitian yang menghasilkan data deskriptif berupa kata-kata tertulis atau lisan dari orang-orang dan perilaku yang dapat diamati" Bodgan dan Taylor dalam Moleong (2010:4).

Menurut moleong (2010:6) bahwa "penelitian kualitatif adalah penelitian yang bermaksud untuk memahami fenomena tentang apa yang dialami oleh subjek penelitian misalnya perilaku, persepsi, motivasi, tindakan dan lain-lain. Karena penelitian kualitatif merupakan penelitian yang memiliki kerangka berfikir dan hasil wawancara, mengingat penelitian yang akan dilakukan hanya menggunakan teori wawancara dilapangan yang akan dibuat menjadi sebuah kerangka karangan deskriptif yang akan bermanfaat bagi khalayak.

Informan penelitian ini meliputi informan kunci dan informan pokok berjumlah 5 orang. Informan kunci adalah mereka yang mengetahui dan memiliki berbagai informasi pokok yang diperlukan dalam penelitian atau informan yang mengetahui secara mendalam permasalahan yang sedang diteliti. Sedangkan informan pokok adalah informan yang ditentukan dengan dasar pertimbangan mengetahui dan berhubungan dengan permasalahan.

\section{HASIL PENELITIAN DAN PEMBAHASAN}

Fungsi komunikasi antarbudaya dalam ritual Kedurai Agung di desa Taba Tembilang antara lain ialah sebelum mengadakan ritual Kedurai Agung, masyarakat seperti ketua suku kepala desa dan aparat desa berkumpul dan bermusyawarah bahwa akan diadakannya ritual Kedurai Agung ini. Pada saat ritual Kedurai Agung ini dilaksanakan semua sesajen yang telah siap dibawa ketempat dukun melakukan ritual dibawah jembatan dipinggir sungai yang ada di desa Taba Tembilang. Irisan jeruk nipis dan kemenyan yang dibakar oleh dukun ini menjadi media untuk berkomunikasi dengan arwah leluhur. Komunikasi nonverbal yang penulis lihat ini dari simbol kemenyan dan jeruk ini yang maknanya sebagai media untuk berkomunikasi memanggil arwah para leluhur dahulu.

Pada saat ritual berlangsung pun masyarakat umum yang menyaksikan ritual ini sangat antusias dan mengikuti serangkaian acara yang ada dan setelah acara melakukan ritual ini selesai dukun dan masyarakat pun kembali ke rumah adat. Untuk mendoakan makanan yang sudah disajikan untuk dimakan bersama-sama dengan warga yang mengikuti proses ritual Kedurai Agung meminta keberkahan pada yang maha kuasa atas nikmat yang diberikan, mengucapkan rasa syukur, masyarakat yang berbeda suku pun diperbolehkan melihat acara ritual Kedurai Agung ini dan mereka pun saling 
mengahargai adat orang Rejang yang selalu diadakan di desa mereka ini. Selain menganalisa makna verbal dan nonverbal dalam ritual Kedurai Agung penulis juga menganalisa komunikasi antarbudaya yang terjadi di desa Taba Tembilang. Dimana penulis melihat fungsi dari komunikasi antarbudaya itu sendiri walaupun berbeda suku dan budaya tetapi masyarakat di desa Taba Tembilang ini hidup rukun damai dan saling menghargai sesama.

Penulis menganalisis komunikasi antarbudaya dalam ritual Kedurai Agung yang ada di desa Taba Tembilang kecamatan Argamakmur Bengkulu Utara. Adapun alat penulis untuk menganalisis adalah dengan melihatfungsi dari komunikasi antarbudaya itu sendiri, yaitu melihat dari fungsi pribadi dan fungsi sosial. Seperti yang kita ketahui bahwa kebudayaan telah mendarah daging dimasyarakat dan sudah menjadi tradisi turun temurun yang ada di desa Taba Tembilang.

\section{Fungsi Pribadi}

\section{Identitas Sosial}

Dalam proses komunikasi antarbudaya terdapat beberapa perilaku komunikasi individu yang digunakan untuk menyatakan identitas sosial. Perilaku itu dinyatakan melalui tindakan berbahasa baik secara verbal dan nonverbal. Dari perilaku berbahasa itulah dapat diketahui identitas diri maupun sosial, misalnya dapat diketahui asal-usul suku, agama, maupun tingkat pendidikan seseorang. Fungsi komunikasi antarbudaya yang menyatakan identitas sosial dapat dilihat dari asal-usul bahasa dan dari suku mana saja masyarakat yang tinggal di desa Taba Tembilang ini untuk menjadikan sebuah identitas sosial yang ada dimasyarakat tersebut. Masyarakat yang tinggal di desa Taba Tembilang ini bukan hanya orang Rejang saja tetapi banyak masyarakat pendatang yang berasal dari berbagai suku dan menetap tinggal di desa Taba Tembilang ini.

Suatu perilaku yang ditunjukan oleh individu yang digunakan untuk menyatakan identitas sosial hal tersebut ditunjukan oleh tindakan masyarakat di desa Taba Tembilang dalam berbahasa baik secara verbal maupun non verbal dari berbahasa itulah dapat diketahui identitas diri, misalnya asal usul suku, agama, maupun berbeda budaya.

Berdasarkan hasil penelitian yang ada di desa Taba Tembilang ini masyarakat yang tinggal menetap berbeda suku dan budaya saling menghargai dan beradaptasi dengan mengikuti serangkaian adat yang ada di desa tempat mereka tinggal. Seperti ritual Kedurai Agung yang selalu dilakukan setiap tahunnya di desa mereka, walaupun ini adat orang Rejang suku lain pun sering berpartisipasi dalam acara-acara besar yang menunjukan bahwa masyarakat yang berbeda suku itu bisa menyatu dan saling menghargai satu sama lain. Inti dari hal ini kebudayaan yang diciptakan manusia dalam kelompok dan wilayah yang berbeda-beda mengahasilkan keragaman kebudayaan termasuk dalam budaya ritual Kedurai Agung tiap persekutuan hidup manusia (masyarakat, suku, atau bangsa) memiliki kebudayaannya sendiri yang berbeda dengan kelompok lainnya.

\section{Menyatakan Integrasi Sosial}

Inti konsep integrasi sosial adalah menerima kesatuan dan persatuan antarpribadi, antar kelompok namun tetap mengakui perbedaan-perbedaan yang dimiliki oleh setiap unsur. Perlu dipahami bahwa salah satu tujuan komunikasi adalah memberikan makna yang sama atas pesan yang dibagi antara komunikator dan komunikan. Dalam kasus komunikasi antarbudaya yang melibatkan perbedaan budaya antar komunikator dengan 
komunikan, maka integrasi sosial merupakan tujuan utama komunikasi.

Fungsi komunikasi antarbudaya terutama untuk integrasi sosial sudah berfungsi secara efektif, hal ini ditunjukkan oleh masyarakat yang berusaha saling memahami dan berusaha untuk beradaptasi dengan kebudayaan yang ada di desa Taba Tembilang terlihat dari kebiasaan masyarakat walaupun berbeda suku dan budaya tetapi masyarakat menerima perbedaan yang ada saling bergotong royong, saling membantu dan ikut berpartisipasi pada saat ritual Kedurai Agung yang dilakukan di desa tempat mereka tinggal.

Konsep integrasi sosial adalah menerima kesatuan dan persatuan antar pribadi atau kelompok dan menerima perbedaan yang dimiliki oleh setiap unsur. Untuk integrasi sosial didesa ini sudah menerima perbedaan antar setiap suku yang ada, dan saling mengahargai satu sama lainnya walaupun berbeda suku. Contohnya pada saat ritual Kedurai Agung berlangsung banyak masyarakat yang menonton bukan saja orang Rejang aslitetapi masyarakat yang berbeda suku pun boleh saja menonton dan mengikuti rangkaian proses ritual yang ada di desa Taba Tembilang. Melihat bagaimana proses ritual Kedurai Agung berlangsung terutama bagi masyarakat yang tinggal disitu tetapi bukan orang Rejang dan masyarakat dari desa tetangga dan masyakat luarpun boleh ikut menyaksikan ritual Kedurai Agung ini.

\section{Menambah Pengetahuan}

Seringkali komunikasi antarbudaya menambah pengetahuan bersama dan saling mempelajari kebudayaan masing-masing. Berkenaan dengan fungsi komunikasi antarbudaya yang menambah pengetahuan di dalam ritual kedurai agung yang ada di desa Taba Tembilang. Dari wawancara dengan informan kunci dan informan pokok di atas dapat disimpulkan bahwa komunikasi antarbudaya untuk menambah pengetahuan sudah berjalan dengan efektif hal tersebut dapat dilihat dari keterangan yang di dapatkan dari informan mereka saling mendapatkan pembelajaran dari acara-acara yang diselenggarakan seperti ritual Kedurai Agung yang ada di desa Taba Tembilang ini, berupaya untuk saling menghargai apabila ada masyarakat yang berbeda budaya (selain suku rejang) yang sedang melakukan ritual adat mereka. Selaku suku pendatang berbeda budaya tetapi saling mengahargai dan ikut berpartisipasi dalam kegiatan apapun yang ada di desa mereka.

Dalam hal ritual Kedurai Agung ini menambah pengetahuan bagaimana proses ritual Kedurai Agung berlangsung terutama bagi masyarakat yang tinggal disitu tetapi bukan suku Rejang, disini suku lainpunsaling mempelajari dan mengetahui kebudayaan adat ritual Kedurai Agung yang selalu dilakukan oleh masyarakat suku Rejang. Masing-masing dari fungsi komunikasi antarbudaya yaitu pengetahuan terlihat dari berbagai unsur budaya di desa Taba Tembilang ini mereka saling mengetahui antara satu dengan yang lain, fungsi pengetahuan sejatinya sudah bawaan dari sejak lahir melalui tahap demi tahap seperti suku Rejang, suku lain juga mengetahui perbedaan-perbedaan yang ada. Hal itu mereka pelajari dengan lamanya mereka tinggal disatu lingkup desa yang sama, masyarakat berusaha untuk dapat memahami sehingga menambah pengetahuan tentang bagaimana ritual Kedurai Agung bagi mereka yang tinggal dalam satu daerah dengan kebudayaan yang berbeda.dan saling menerima perbedaan yang ada dilingkungan tempat mereka tinggal tersebut. 


\section{Fungsi Sosial}

\section{Kepengawasan}

Fungsi sosial yang pertama adalah pengawasan. Praktek komunikasi antarbudaya diantara komunikator dan komunikan yang berbeda kebudayaan berfungsi saling mengawasi. Dalam setiap proses komunikasi antarbudaya fungsi ini bermanfaat untuk menginformasikan "perkembangan" tentang lingkungan. Fungsi ini lebih banyak dilakukan oleh media massa yang menyebarluaskan secara rutin perkembangan peristiwa yang terjadi disekitar kita meskipun peristiwa itu terjadi dalam sebuah kontek kebudayaan yang berbeda. Berkenaan dengan fungsi komunikasi antarbudaya yang saling mengawasi didalam ritual adat Kedurai Agung yang ada di desa Taba Tembilang. Komunikasi antarbudaya terutama untuk fungsi sosial kepengawasan terjalin secara baik, masing-masing individu sudah menyadari akan pentingnya hal dalam saling mengawasi agar sebuah ritual yang sakral dapat berlangsung sesuai apa yang diharapkan.

Pada saat ritual Kedurai Agung berlangsung masyarakat yang ada di desa Taba Tembilang walaupun berbeda budaya dan berbeda suku mereka tetap saling mengawasi dan ikut berpartisipasi mengikuti serangkaian adat yang ada di desa mereka tinggal. Fungsi komunikasi antarbudaya kepengawasan ialah komunikator dan komunikan berbeda budaya saling mengawasi antara yang satu dengan yang lain. Fungsi komunikasi antarbudaya kepengawasan di desa Taba Tembilang sudah mereka terapkan tanpa mereka sadari masing-masing dari suku yang berbeda saling menjaga antara satu dengan yang lain. Contohnya pada saat acara ritual Kedurai Agung berlangsung masyarakat di desa Taba Tembilang bermusyawarah bersama mengumpulkan semua pemuka adat dan suku yang berbeda untuk tetap saling mengawasi dan saling mengahargai antar sesama.

\section{Menjembatani}

Menjembatani dalam proses komunikasi antarbudaya, maka fungsi komunikasi yang dilakukan antara dua orang yang berbeda budaya itu merupakan jembatan atas perbedaan diantara mereka. Fungsi menjembantani itu dapat terkontrol melalui pesan-pesan yang mereka pertukarkan makna yang sama untuk memperoleh informasi tentang komunikasi antarbudaya yang menjembatani. Komunikasi antarbudaya dalam menjembatani disini terlihat ketika adanya ritual Kedurai Agung yang diadakan di desa Taba Tembilang ini masyarakat saling membantu dan menjadi ajang untuk bergaul karena pada saat acara ini banyak warga masyarakat yang berkumpul walaupun hanya sekedar menyaksikannya saja dan dapat mempererat tali silahturahmi yang baik dalam kehidupan sehari-hari di masyarakat dengan adanya perbedaan suku dan budaya inilah menjadikan hubungan semakin dekat dan harmonis.

Pada saat ritual Kedurai Agung berlangsung masyarakat Rejang bisa menjelaskankepada suku lain mengenai adat ritual Kedurai Agung yang ada di desa Taba Tembilang ini. Komunikasi yang dilakukan oleh dua orang yang berbeda budaya hal itu merupakan jembatan atas perbedaan mereka keduanya saling menjelaskan perbedaan tafsir atas sebuah pesan sehingga menghasilkan makna yang sama. Dalam fungsi komunikasi antarbudaya di desa Taba Tembilang, sebagaimana kita ketahui di setiap desa sudah pasti memiliki adat istadat sebagai jembatan untuk menyatukan silahturahmi dengan masyarakat yang berbeda suku dan budaya. 


\section{Sosialisasi}

Nilai fungsi sosialisasi merupakan fungsi untuk mengajarkan dan memperkenalkan nilai-nilai kebudayaan suatu masyarakat ke masyarakat lain. Fungsi komunikasi antarbudaya yang merupakan fungsi sosial dapat dikatakan bahwa masyarakat yang berbeda budaya sudah memahami akan kebiasaan dalam ritual Kedurai Agung yang ada di desa Taba Tembilang, sehingga perlu diadakannya sosialisasi kepada masyarakat seperti kebiasaan yang ada didesa tersebut. Nilai yang terdapat dalam ritual Kedurai Agung ini seperti nilai kekeluargaan, kebersamaan, bekerjasama dalam bergotong royong kerena di desa ini masih sangat kental.

Fungsi sosialisasi ialah mengajarkan dan memperkenalkan nilai-nilai yang ada dalam ritual Kedurai Agung. Nilai yang terkandung dalam ritual Kedurai Agung ini masih sangat kental dapat dilihat dari kebersamaan, saling menghargai dan bekerjasama dalam bergotong-royong. Pemuka adat yang mensosialisasikan ritual Kedurai Agung dengan nilai-nilai kebudayaan di desa Taba Tembilang ini, sangat baik karena mereka menyadari betapa pentingnya mempelajari kebudayaan-kebudayaan yang ada. Hal tersebut mereka dapatkan dengan lamanya mereka tinggal di satu lingkup desa yang sama hal tersebut juga membuat mereka saling mempelajari memahami kebudayaan masing-masing suku.

\section{Menghibur}

Fungsi menghibur juga sering tampil dalam proses komunikasi antarbudaya. Misalnya menonton tarian dari kebudayaan lain. Hiburan termasuk dalam kategori hiburan antarbudaya. Untuk memperoleh informasi yang lebih jelas lagi di dalam ritual Kedurai Agung berdasarkan fungsi komunikasi antarbudaya fungsi sosial menghibur peneliti melakukan wawancara dengan informan setempat. Komunikasi antarbudaya terutama untuk fungsi menghibur terlihat pada pernyataan informan kunci dan informan pokok di desa Taba Tembilang ini khususnya menghibur terlihat dari kebiasaan masyarakat dalam mengadakan ritual Keduri Agung ini. Menjadi hiburan tersendiri bagi masyarakat walaupun berbeda suku dan berbeda budaya tetapiadanya sikap saling mengahargai.

Dengan adanya ritual Kedurai Agung yang ada di desa Taba Tembilang ini masyarakat yang sangat antusias menonton tradisi yang hanya satu tahun sekali diadakan di desa Taba Tembilang ini, menjadi sebuah hiburan tersendiri bagi masyarakat yang menyaksikannya.dan banyak masyarakat dari luar yang berbeda suku dan budaya ikut menyaksikan acara ritual Kedurai Agung yang sedang berlangsung ini.Hiburan termasuk dalam kategori hiburan antarbudaya.Fungsi komunikasi antarbudaya dapat dikatakan menghibur di desa ini terlihat dengan jelas dari informasi yang diperoleh karena ritual yang sakral yang diadakan di desa mereka yang hanya satu tahun sekali diadakan dan walaupun banyak suku yang berbeda tetapi memiliki rasa kepedulian dan saling menghormati sesama walaupun berbeda budaya.

Berdasarkan penelitian dan observasi secara langsung di desa Taba Tembilang maka dapat diketahui bahwa di desa Taba Tembilang ini walaupun berbeda suku dan budaya tetapi saling menghargai dan menghormati.Dan rasa kekeluargaan yang tinggi dalam menjalin silahturahmi dan keikut sertaan dalam segala hal dalam acaraacara besar seperti ritual Kedurai Agung yang ada di desa tempat mereka tinggal.

\section{PENUTUP}

Setelah peneliti melakukan observasi awal hingga dilanjutkan penelitian maka peneliti ingin melihat bagaimana analisis komunikasi antarbudaya dalam ritual 
Kedurai Agung ini masyarakat yang tinggal di desa Taba Tembilangbahwasanya mereka tidak membedakan dari suku manapun, diperbolehkan ikut serta dalam ritual Kedurai Agung. Tetapi walaupun berbeda suku dan bukan asli orang Rejang yang mempunyai tradisi ini masyarakat yang berbeda budaya dan suku pun ikut andil dan ikut serta dalam acara ritual Kedurai Agung dan mereka saling menghargai adat yang ada didesa tempat mereka menetap.

\section{Fungsi Pribadi}

Melalui identitas sosial masyarakat desa Taba Tembilang yang menerima kesatuan dan persatuan antarpribadi, antar kelompok tapi tetap mengakui perbedaan-perbedaan yang dimiliki oleh setiap unsur berbeda. Karena masyarakat yang tinggal di desa Taba Tembilang ini bukan hanya masyarakat Rejang saja tetapi banyak masyarakat pendatang seperti suku Jawa, suku Serawai dan suku Minang yang tinggal di satu daerah dan saling menghargai perbedaan suku tersebut.Dengan adanya ritual Kedurai Agung yang selalu diadakan hanya satu tahun sekali ini menambah pengetahuan bersama dan saling mempelajari kebudayaan masing-masing.

\section{Fungsi Sosial}

Masing-masing individu sudah menyadari akan pentingnya hal dalam saling mengawasi ritual Kedurai Agung yang berlangsung sesuai dengan apa yang diharapkan.Masyarakat yang berbeda budaya sudah memahami akan kebiasaan dalam ritual Kedurai Agung yang ada di desa tempat mereka tinggal. Kebiasaan masyarakat dalam mengadakan ritual Kedurai Agung ini, selain berkumpul menjalin silahturahmi antar sesama masyarakat yang tinggal satu daerah juga menjadi hiburan/tontonan tersendiri bagi masyarakat walaupun berbeda suku dan budaya antusias menonton dan berpartisipasi pun masih terlihat kuat di desa Taba Tembilang ini.

\section{DAFTAR PUSTAKA}

Bungin, Burhan. 2009. Sosiologi Komunikasi. Jakarta: Kencana Prenada Media Group

Cangara, Hafied. 2014. Pengantar Ilmu Komunikasi. Jakarta: RajawaliPers

Darmawansyah. 2016. Analisis Komunikasi Antarbudaya Dalam Pernikahan Di Desa Temiang Kecamatan Pagar Jati Bengkulu Tengah..Universitas Dehasen Bengkulu. Skripsi

Effendy, Onong Uchjana. 2007. Ilmu Komunikasi Teori Dan Praktek Pt.Remaja Rosdakarya

Kriyantono, Rachmat. 2012. Teknik Praktis Riset Komunikasi. Jakarta, Kencana Prenada Media Group

Liliweri, Alo. 2003. Dasar-Dasar Komunikasi Antar Budaya. Yogyakarta, Pustaka Pelajar

Moleong, 2013.Penelitian Kualitatif, Jakarta, Rineka Cipta

Morissan, 2013.Teori Komunikasi. Jakarta, Prenanda Media Group

Muchammad Arief Sigit Muttaqien. 2009. Komunikasi Antarbudaya ( Studi Pada Pola Komunikasi Masyarakat Muhammadiyah Dan NU Di Desa Pringapus, Semarang, Jawa Tengah ). Universitas Islam Negeri Syarif Hidayatullah Jakarta. Skripsi

Muhammad Lapsee Chesoh. 2016. Komunikasi Antarbudaya (Studi Model Komunikasi Mahasiswa Pattani Uin Sunan Kalijaga Terhadap Masyarakat Gowok Yogyakarta). Universitas Islam Negeri Sunan Kalijaga Yogyakarta. Skripsi

Mulyana, Deddy. 2001 Komunikasi Antar Budaya. Bandung, PT Remaja Rosdakarya 
Jurnal Professional FIS UNIVED Vol.5 No.2 Desember 2018

Mulyana, Deddy.2004.Komunikasi Efektif, Bandung , PT RemajaRosdakarya

Mulyana,Deddy.2014.Komunikasi Antar Budaya. Bandung, PT RemajaRosdakarya

Koentjaraningrat, 2009. Pengantar Ilmu Antropologi. Jakarta, PT. Rineka Cipta.

Rakhmat, Jalalludin. 2003. Psikologi Komunikasi. Bandung: Remaja Rosdakarya.

Sugiyono. 2013. Metode Penelitian Kombinasi (Mixed Methods). Bandung: Alfabeta
Sihabudin, Ahmad .2013 Komunikasi Antar Budaya. Jakarta, PT BumiAksara

Suyanto, Slamet. 2005. Dasar-Dasar Pendidikan Anak Usia Dini. Yogyakarta, Hikayat

Sobur, Alex. 2013. Semiotika Komunikasi. Bandung, RemajaRosdakarya

West Richard \& H. Turner Lynn. 2008. Pengantar Teori Komunikasi; Analisis dan Aplikasi. Jakarta, Salemba Humanika. 